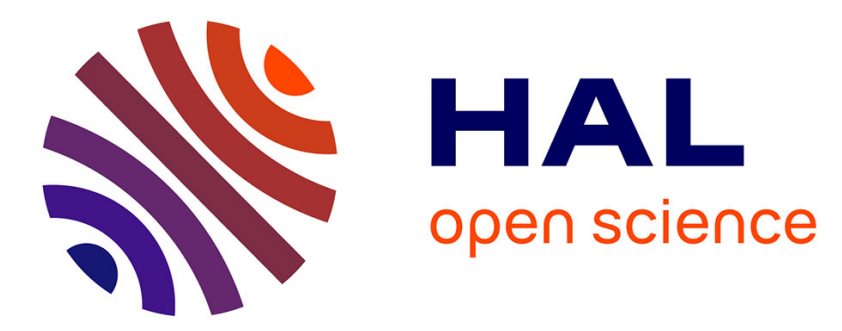

\title{
How to Testify to the Emergence of an Idea in Conversation: Methodological Avenues for Exploring Children's Interviews

\author{
Christine Sorsana
}

\section{- To cite this version:}

Christine Sorsana. How to Testify to the Emergence of an Idea in Conversation: Methodological Avenues for Exploring Children's Interviews. Human Development, 2021, 64 (3), pp.142-159. 10.1159/000512774. hal-03194761

\section{HAL Id: hal-03194761 \\ https://hal.science/hal-03194761}

Submitted on 9 Apr 2021

HAL is a multi-disciplinary open access archive for the deposit and dissemination of scientific research documents, whether they are published or not. The documents may come from teaching and research institutions in France or abroad, or from public or private research centers.
L'archive ouverte pluridisciplinaire HAL, est destinée au dépôt et à la diffusion de documents scientifiques de niveau recherche, publiés ou non, émanant des établissements d'enseignement et de recherche français ou étrangers, des laboratoires publics ou privés. 
REFERENCE TO BE USED FOR ANY QUOTATION OF THIS WORK:

Sorsana, C. (2020). How to testify to the emergence of an idea in conversation: Methodological avenues for exploring children's interviews. Human Development, 64, 142-159.

https://doi.org/10.1159/000512774

\title{
How to Testify to the Emergence of an Idea in Conversation: Methodological Avenues for Exploring Children's Interviews
}

\begin{abstract}
.
In line with socioconstructivist works analysing the impact of social interactions on cognitive development, the present study discusses how to capture, describe, and analyse the emergent co-production of new ideas or creative cognitive solutions. After introducing the methodologies that are currently used in this field, we recall the relevance of pragmatic analyses of conversations. We then identify several possible methodologies for probing and finely analysing the emergence of children's new thinking, by cross-referencing third-person (i.e., from the researcher's point of view) and first-person (i.e., from the children's point of view, following an explicitation interview) analyses.
\end{abstract}

The assumption that social interaction constitutes the matrix of cognitions comes in two versions (Trognon, 1991). The weak version considers interaction to be "the bath from which cognitions emerge" (p. 20). In other words, interaction acts as a catalyst or mediator between individuals and the knowledge to be acquired (or internalized). The strong version assumes that "the emergence of cognitions is achieved in the unfolding of interaction" (Trognon, 1991, p. 20). An interaction can therefore take place in one of two ways: one, the unfolding of interaction plays its role statically: interaction is perceived either as (a) a container of the partners' thought processes, (b) supplying matter for these processes, or (c) offering models of these processes that people can internalize; two, the unfolding of interaction plays its role dynamically, insofar as the partners (a) help each other to deliver (Aristotelian meaning) cognitions that are already starting to take form in their thoughts, or (b) co-produce absolutely fresh cognitions that cannot be reduced to the sum of their individual cognitions. All cognitive functioning probably relies on each of these versions to some extent. The question is how to capture, describe, and analyse these co-productions of new ideas or creative cognitive solutions when they appear. The main aim of this article is to promote an answer to this question in the field of children's sociocognitive development.

In order to answer this question concerning children in a problem-solving situation, this paper is built on three sections. First, we underline that a plethora of assumptions about the relevant characteristics of interactions favouring cognitive development exist in the socioconstructivist developmental field. Among the socioconstructivist developmental methodologies, conversation is considered as a locus for the co-production of new ideas in and/or through interaction. Some researchers analyse conversations using pre-established categories whereas others focus on the sequential unfolding of conversations, without preset categories. In line with an ethnomethodology approach, the latter methodology makes it possible to consider the psychological repercussions of the only contextual and individual features (or parameters) that are relevant from the point of view of the co-actors in situ. In the second section, we emphasize what we have learned from pragmatic analyses of conversations focused on sequentiality, and especially from interlocutory logic research findings. We give three examples ${ }^{1}$ to illustrate that these interlocutory analysis studies allow researchers to infer potential sociocognitive paths to solving the given problem, interpreting the content of the representations exchanged by the interlocutors from the perspective of an observer, and so, producing a "third-person" analysis (i.e., from the researcher's point of view). In order to go thoroughly into the understanding of the reasoning paths actually accomplished between children in a problem-solving situation, in the last section, we advocate to combine the interlocutory analyses of conversations with a technique of interview which allows the researchers to have access to the point of view of the children 
themselves: the explicitation interview. In other words, we argue for cross-referencing observations of the partners' behaviours and logics (via analyses of conversation or third-person accounts) with the participants' own thoughts about their actions and logics (via the explicitation interview or first-person accounts). At first elaborated for guiding adults (Vermersch, 1994, 2009, 2012), the explicitation interview is also used with children in school settings to guide the interviewee's introspection, prompting them to describe with detail their past activity in order to find out what they actually did. We set out the main characteristics of this technique. Finally, we propose an exploratory research design for interviewing children in order to bridge the gap between different levels of analysis, namely the objective and subjective levels of analysing sociocognitive processes.

\section{Socioconstructivist Developmental Methodologies}

While there is a consensus in the socioconstructivist developmental research community as to how to analyse semiotic mediations (particularly linguistic ones), divergences remain concerning the choice of methods to adequately describe and explain the sociocognitive dynamics at play in problem-solving or learning contexts (Danis et al., 2003; Gilly et al., 1999; Hinde et al., 1985; Perret-Clermont, 1993; PerretClermont \& Nicolet, 2001; Psaltis et al., 2015; Schwarz \& Baker, 2016; Sorsana, 1999, 2011; van Eemeren \& Garssen, 2015; Zittoun \& Iannaccone, 2014).

The socioconstructivist approach of cognitive development (Gilly, 1989, 1991; Mugny \& Doise, 1978; Mugny et al., 1981; Perret-Clermont, 1993; Psaltis et al., 2009; Sorsana, 1999; Sorsana \& Trognon, 2011) assumes that knowledge and know-how are built in and through social interactions. In other words, individuals are both conceptualized as a centre of decision, and as a point of intersection of several lines of force that can be analysed at different levels: intra-individual, inter-individual, situational, social position, or ideological (Doise, 1986). Initially, "socioconstructivist" developmental research was concerned with the studies - following the Piagetian constructivist and structuralist theory - that showed empirical evidence of the impact of social interactions on cognitive development (see the princeps works made by Doise et al., 1975), whereas "socio-historical" developmental research was concerned with the studies following the Vygotskian theory (e.g., Bruner, 1986, 1990, 1996; Wertsch, 2008). In the former studies, children were generally observed within symmetrical interactions between peers (i.e., no difference of children's knowledge related to the task was mentioned by the experimenter) whereas in the latter ones, the observed interactions were asymmetrical (i.e., a performer child to the task interacted with a novice partner or an adult interacted with a child). Moreover, in the former studies, researchers focused on hic et nunc interactions whereas in the latter ones, they attended to (i) historical and cultural features that impacted the social and cognitive dynamics observed as well as to (ii) the fundamental role of language as a "psychological instrument" for thinking development. Today, such a distinction is no longer relevant because the scientists of the socioconstructivist developmental field have progressively integrated the historical and cultural dimensions when they have studied the tangled lines of force that constitute the psychological organization of thinking development. The "historico-cultural" wording encompasses all these developmental models that take into account the social, historical, and cultural phenomena. Here are the theoretical developmental backgrounds from which we will situate our proposal. We are not unaware that a lot of other research deals with the idea that human cognition is shaped by social interaction and sociocultural environments, but it does not always assume that knowledge and know-how are built in and through social interactions. From an evolutionary approach to human cognition, cognitive scientists have argued that reasoning is a social skill (Mercier \& Sperber, 2011), but only for the pursuit of individual benefits $^{2}$. Regarding children's sociocognitive development, Tomasello's work $(1999,2014)$ showed how evolutionary, historical, and ontogenetic processes shape human cognition. Nevertheless, according to him, social and cultural processes do not create cognitive skills during ontogenesis; these ontogenetic processes convert the primitive cognitive skills onto extremely sophisticated and complex ones.

\section{A Plethora of Assumptions about the Relevant Characteristics of Interactions Favouring Cognitive Development}


Although historico-cultural developmental authors agree that the impact of social interaction needs to be understood within the framework of a systemic model of thinking processes, taking physical, cognitive, interactional, social, and cultural characteristics into account, many researchers continue to add to the list of potentially relevant (or necessary) parameters to be considered when exploring the development of new cognitions: e.g., age, gender, social class, academic status, etc. Moreover, a number of different types of experimental or observational scenarios have been developed in parallel, with the goals of (a) eliciting sociocognitive processes in experimental designs versus observing genuine sociocognitive interactions in natural settings, (b) focusing on symmetrical versus asymmetrical interactions, (c) analysing these interactions according to pre-established behavioural and verbal categories versus a step-by-step approach, and (d) focusing on one particular level of analysis in order to articulate cognitive and social characteristics (Doise, 1986).

Although historico-cultural developmental researchers share the same questions, they have come up with a wide set of assumptions to explain the interactional specificities of thinking development, including transactive dialogue (Azmitia \& Montgomery, 1993), exploratory talk (Mercer, 2000) ${ }^{4}$, explicit recognition (Psaltis \& Duveen, 2006, 2007) ${ }^{5}$, or thinking spaces (Perret-Clermont, 2001, 2003, 2015) . Analyses of semiotic mediations in the field of training in interaction are therefore many and various. In these works, the researchers used different category frames of analysis, based on conversations that were videotaped, transcribed, and analysed by two judges. The different categories were selected according to the goals followed. For example, Psaltis and Duveen (2006) constructed different sets of measures for examining "outcomes," "conversational features," and "conversation types" in order to measure possible outcomes in terms of individual cognitive progress as well as "to capture the nature and quality of the engagement of the partners in the interactions" (p. 414). For other researchers, the category frames took into account the characteristics of the argumentation between partners: recaps, elicitations, repetitions, reformulations, and exhortations (referring back to shared experiences, eliciting or offering information, justifying ideas or proposals, evaluating others' contributions, repeating and reformulating each other's statements) (Mercer, 2000, pp. 52-56). As a consequence, findings are difficult to compare, even though they share a common ground and common objectives. In addition, it has become commonplace to argue that further discovery of a multitude of other parameters ${ }^{7}$ - heuristic, relevant, or necessary - will never exhaust all the potential sources of variation, for although a given situation can be formally described as being identical for all the participants, it will never be lived and interpreted in an identical way. Nevertheless, the singularity of individuals' interpretations does not mean that there are no regularities in the ways they behave, interact, and interpret the world. Researchers can locate and explore these regularities, providing they bear in mind that these regularities only make sense to the observer (i.e., from the third person's point of view; see Maturana \& Varela, 1992).

\section{Conversation as a Locus for the Co-Production of New Ideas}

How can we identify the interpretations that make sense to the interlocutors in a given situation, and how can we grasp the psychological repercussions of the parameters identified as relevant by the co-actors in situ? We assume that conversation constitutes a favourable locus for co-producing new ideas, but why?

Owing to its empirical properties (or constraints) (Schegloff, 1991; Trognon, 1993, 2001; Turkle, 2015), conversation is the primary meeting place for human beings, but one where regularities and disturbances coexist, generating the dynamics for creative thinking. It is an event that is directed, irreversible, and gradually organized by a succession of joint (social and cognitive) actions. These actions are local, do not follow any predetermined plan, and are distributed between all the interlocutors. This talking-together event produces original and unpredictable ideas, emotions, and social relationships in the form of illocutions (Sorsana, 2003; Sorsana \& Trognon, 2018). As such, this located and distributed activity under perpetual construction allows thinking to take place, based not on the absolute truth about what is being talked about, but on the degree of truth the interlocutors attribute to each other's representations, in a fiduciary pact (i.e., one grounded in trust; Manes Gallo \& Vernant, 1997). 
To empirically identify the emergence of fresh thinking in conversation, historico-cultural developmental researchers currently use two types of methodology, sometimes in combination (Sorsana \& Trognon, 2011). Some adopt an additive conception of interaction, analysing social interactions by creating an open-ended list of properties from various sources, for example on "the balance of a variety of sources of asymmetry of status (gender, age, ethnic origin, popularity, academic reputation, social class, inter alia) ..." (Psaltis, 2011, p. 239). Using pre-established categories to code behaviours and/or speech (Felton \& Kuhn, 2001; Mercer, 2000; Olry-Louis \& Soidet, 2008; Psaltis \& Duveen, 2006, 2007; Tartas \& PerretClermont, 2008; Tartas et al., 2010) ${ }^{8}$ implicitly conveys the idea that an interaction can be understood as a closed system. Others analyse social interactions within conversations by focusing on sequentiality ${ }^{9}$, with no pre-established categories. They work on the assumption that within interlocutions, all the levels of analysis identified by Doise (1986) are inseparable and engaged at the same time (Trognon et al., 2011b). The question then is how to capture all the material, cognitive, and relational properties that simultaneously appear in the flow of conversational interactions, and that matter for interacting individuals as they are coupled with their environment (Varela et al., 1991). Indeed, in everyday activities, thinking, emotional, and social relationships are forged at the same time as they are intersubjectively identified (Goffman, 1967). The properties that are relevant to the pursuit of the conversation within interactions are recognized by the analyst-researcher at the same time as they are uttered by the partners, as they are coded at the semiotic level and rendered visible and public by the interlocutions: for example, the researcher can understand that the partners have divergent points of view about the way to solve the problem, and that one of them tries to have power over their partner, or, on the contrary, the researcher can understand that trust between the partners is based on their close relationships. Speaking is acting (Austin, 1962), and each speech is coloured by the social positions as well as the representations of the world from which each speaker talks, and by the kind of social and emotional relationships enacted between them. We therefore do not need to know or categorize what seems to be important for the people before they become visible in the flow of the partners' exchanges. Nevertheless, when somebody says: "Oh, I see what you say! Now, I understand!" or when a dyad performs a cognitive task in a very innovative way, deeper analyses should be done in order to identify the (endogenous and/or interpersonal) source of such insights. Among these analyses, the exploration of the pre-reflective part of the partners' experience is likely to open new directions to investigate and to understand the sociocognitive processes of thinking development (as we will see in the final section).

We now know that any interaction at the same time co-builds its deployment, its objects, and its resources, which are not preliminary to its achievement and do not belong to only one speaker's intentionality (Mondada, 2004). Moreover, ethnomethodology research has shown that social facts cannot be described by a priori categories (Garfinkel, 1967; Heritage, 1984, 1990). These social and cognitive facts are constructed from procedures and products of the methodically achieved actions, accomplished by people as co-actors, and can only be captured using a method that focuses on the temporal dimension of the interactional flow (i.e., with a sequential analysis, and no pre-established categories). To undertake this type of analysis, researchers can rely on the relation of order which organizes the various partners' actions, according to the logical relations between the properties of these actions (Trognon, 1993, 2001). Just as it is probably impossible to exhaustively list all the parameters involved in the development of new thinking and thoughts, it is probably impossible to categorize all the potential sociocognitive trajectories related to learning or problem solving. In other words, the ways in which the mind grasps the elements that allow it to transform, consolidate, or increase its abilities are probably unforeseeable. As a result, instead of grappling with a never-ending list of elements that can potentially describe and explain cognitive development, it seems more reasonable to adopt a methodology that can capture the tangled levels of the interpretative system enacted by interlocutors coupled with a given situation. This methodology makes it possible to consider the psychological repercussions of the only parameters that are relevant from the point of view of the co-actors in situ.

\section{What Have We Learned from Pragmatic Analyses of Conversation?}




\section{Overview of the Advantages of Pragmatic Analyses}

Pragmatics is an area of linguistics that concerns the relations between signs and their users (i.e., how people use signs to influence their interlocutors). In other words, pragmatics consists in describing the meaning of utterances in context and provides a theoretical framework and methodological tools for understanding how social, emotional, and cognitive features are intertwined within the problem-solving strategies used by individuals. Studying pragmatics and its effects on cognitive performance may involve different goals, depending on the researchers' theoretical conceptions. From the evolutionary point of view, argumentative activity is the primitive function of human reasoning (Mercier \& Sperber, 2011), and conversation constitutes a kind of primary matrix, where social relationships and thinking are accomplished through language use (Trognon \& Batt, 2013). In the experimental psychology of reasoning, the pragmatic impact of the instructions, and more generally of the experimental design, is analysed in order to understand what precise pragmatic disorder is responsible for the (apparent) disparity of the experimental results (Politzer, 2004; Politzer \& Macchi, 2000) $)^{10}$. By contrast, from the historical-cultural perspective, conversation is at the same time an instrument, an object, and a source of knowledge (Veneziano, 1999). This psychosocial approach to pragmatics considers that every statement is a joint activity involving at least two interacting people, each with a particular status, role, and objective (Ghiglione \& Trognon, 1993).

Different ways to analyse conversational interactions exist (philosophical, linguistic, ethnosociological, psychological, and psychiatric research trends). In order to situate our discussion, we have to distinguish "conversational analysis" from "analysis of conversations." "Conversational analysis," coming from ethnomethodology (Garfinkel, 1967; Heritage, 1984, 1990; Sacks et al., 1974; Schegloff, 1991), aims at describing and explaining the various and strongly context-dependent rules that underlie the accomplishment of daily interactions in natural settings. In other words, the matter is to decode the "invisible music" that guides (with flexibility) people's behaviours when they are engaged in this polyphonic and complex activity that a conversation is (Kerbrat-Orecchioni, 1996). To this end, researchers adopt a global analysis of the conversational sequences in order to locate the normative structures of reasoning (namely, ethnomethods), which are involved in understanding and producing daily interactions. In concrete terms, they meticulously describe the procedures that people are accomplishing in order to negotiate their behaviours and to understand each other in the unfolding daily interaction (Corsaro, 1997; Goodwin, 2000, 2007; Greenfield \& Lave, 1982; Karlsson et al., 2017; Kyratzis, 2004; Kyratzis \& ErvinTripp, 1999; Kyratzis \& Jean Johnson, 2017; Kyratzis et al., 2010; Lave, 1988; Lave \& Wenger, 1991; Rogoff, 1990; Rogoff \& Angelillo, 2002; Saxe, 1988, 2002; Schliemann et al., 1997). By contrast, "analysis of conversations" - to which we specifically refer - is a cognitivist approach of interaction that attaches the greatest importance to the Speech Acts theory and to the discourse structuration (Austin, 1962; Searle \& Vanderveken, 1985; Vanderveken, 1990). The ethnomethodological analysis is combined with other analyses permitted by cognitive theories of communication, such as Grice's $(1975,1989)$ or Sperber and Wilson's (1995). In concrete terms, the descriptions so produced lead to formal analyses of conversations (Moeschler, 1985, 1993; Roulet, 1992; Roulet et al., 1985; Trognon, 1993, 2001).

According to Austin (1962), all utterances are acts. An illocutionary act is an elementary unit of communication that carries out an action (order, request, assertion, promise, etc.) and is intended to modify the interlocutors' situation. This speech act $\mathrm{F}(\mathrm{p})$ can be broken down into two components: propositional content (p), which corresponds to the idea (or representation) conveyed in the utterance; and illocutionary force (or value) (F), which corresponds to the social colouring used to express this propositional content. Every speech act takes place within an institutional framework that defines the partners' rights and obligations. It also has logical properties (success, satisfaction, and non-defectiveness; Ghiglione \& Trognon, 1993; Searle \& Vanderveken, 1985; Trognon et al., 2011a; Vanderveken, 1990). In a conversation analysis model, speech acts reflect the reciprocal dependence of the sociocognitive dimensions of the dialogical activity. Moreover, pragmatic analysis provides an opportunity to go beyond the strictly linguistic material. Within the partners' speech turns, certain non-linguistic behaviours (gestures, facial expressions, intonation of the voice, etc.) can elicit the interlocutor's verbal actions. As all the behaviours 
between interacting individuals are constrained by the sequential order (i.e., speech/behaviour turns), any gesture, facial expression, or intonation of the voice that elicits a verbal answer can legitimately be analysed as belonging to the register of speech acts (Kendon, 1995; Larrue \& Trognon, 1993).

Thus, conversing cannot be summarized simply by interpreting the utterances in context, and instead requires interactional competence (Eerdmans, 2003; Trognon \& Sorsana, 2005). Conversing involves genuine engagement between interlocutors, mobilizing a whole set of bio-psycho-sociological phenomena directed towards either an instrumental (i.e., to coordinate the realization of a task) or simply an interactional (i.e., to be together) end. In pragmatic analyses, any utterance is at the same time a verbal action, a social act, and a sociocognitive activity:

First, we should remember that saying is also acting. A speech act is an act, a verbal action, or more broadly a language act, but basically a social activity. The interaction that lends it meaning is a located and joint activity. This is why it is a question not only of feeling, believing or knowing, but also of making the other person feel, believe or know. When I say "It will rain," my utterance is intended to make other people believe what I feel. It is indeed an inter-action, which is intended to convince and to share information (when I am sincere). It is manifest in the case of knowledge, which results from an explicit share and agreement on built information. (Vernant, 1998, p. 14)

Pragmatic analyses of sociocognitive interactions come in several forms (Bernicot et al., 2002; Gilly et al., 1999; Muller Mirza \& Perret-Clermont, 2009; Psaltis \& Duveen, 2006, 2007; Sorsana, 2003; Sorsana \& Musiol, 2005; Teasley, 1995; Trognon et al., 2003, 2008; Weil-Barais, 2011). Some of them seek to formalize these interactions (see Baker, 2009, for dialogue between learners; Rips, 1998, for argumentative engagement as a result of rules defined from conversational movements; Trognon et al., 2011a, for logical approaches to dialogue). Among these forms of pragmatic analysis, interlocutory logic offers a means of demonstrating the gradual construction of thinking, using logical tools (i.e., natural deduction and dialogical logic) to highlight the intuitive properties of spontaneous sequences of human reasoning in argumentation (Trognon \& Batt, 2010; Trognon et al., 2011c). Whichever methodology is selected, the analyst-researcher interprets the content of the representations exchanged by the interlocutors from the perspective of an observer, producing a third-person analysis.

\section{What Have We Learned?}

Let us see what we have learned from pragmatic analyses of social interactions in problem-solving or learning contexts, and more particularly from the interlocutory logic research undertaken by Alain Trognon and colleagues. Initially, the aim was to produce detailed descriptions of the sociocognitive organization of interlocutions, using a system of formal procedures that respected their phenomenal characteristics as far as possible. Since the 2000s, and taking this system of formal procedures as a starting point, a second aim has been to form assumptions about the most probable communicative and cognitive path that is co-built during the conversational and reflective activity, and which may or may not lead to the discovery of a new solution during and/or as a result of the interaction. The formalization of this communicative and cognitive advance has allowed researchers to infer the distributed social and cognitive processes between interacting individuals, and to capture the hypotheses (or fragments of ideas) that circulate between the partners. Trognon et al.'s (2003) article seems to us to be the prototypical illustration of this second aim. Using the conversational corpus of two adolescents jointly solving a problem of proportionality, these authors show how it is possible to infer several potential sociocognitive paths to solving the problem, i.e., "to understand by which cognitive means - either alone or in collaboration with their partner - the interlocutors state their proposals" (Trognon et al., 2003, p. 4).

\section{When One Thinking Advance Is More Probable than Another}

In some situations, sequential analyses indicate the greater probability of one particular type of effective reasoning. For example, a formal analysis of the conversation between two 10-year-old pupils solving an arithmetic problem allowed researchers to demonstrate how two differentiated procedural paths led to the co-construction of a conceptualization-in-act of the arithmetic principle of division (Trognon et 
al., 2010). A meticulous interlocutory analysis showed how some cognitive, interactional, and communicational micromoves emerged on line and were responsible for the transformation and coconstruction of the children's own ways of thinking. Decisive dialogical events were identified in the pupils' conversation, such as the joint reformulation of the instruction, an inner movement of dialogue, and the successive introduction of (a) a deduction, (b) an idea complementing the partner's proposal, (c) an alternative proposal partially validating the partner's idea, and (d) a restriction. The sequential unfolding of these dialogical events illustrated a highly collaborative interaction that led to a joint creative solution ${ }^{11}$. At a molar level of analysis, the questions formulated by each of the two children seemed identical ("How many shelves are needed to hold the video cassettes?"). However, at a deeper level of analysis, the researchers identified differences in the children's representations of the task (number of shelves per bookcase for one child vs. total number of shelves needed to hold all the video cassettes for the second one) and their respective reasoning processes (multiplication vs. division). Accordingly, with regard to the two cognitive paths available for reaching the solution, the formal analysis pinpointed the crucial moment in the interaction where one sociocognitive advance prevailed over the other. More specifically, one pupil's initial suggestion transformed the way of thinking of the other pupil, enabling the latter to produce an enriched cognition. This proposal was then jointly adopted, leading to the formulation of the correct solution. As observed elsewhere, the children in this successful dyad behaved as though they were friends, in that they were attentive to the conversational management of possible disagreements, and sought to save each other's face, by using implicit formats (attenuating expressions such as "perhaps," "but"; questions (instead of orders) such as “Don't you want to do X?").

\section{When Relational Regulations Foster Cognitive Progress}

Other interlocutory analysis studies have focused on 6- to 8-year-old children sharing (or not sharing) positive relationships (i.e., affinity relationships ${ }^{12}$ ) and attempting to solve a problem. These analyses have allowed authors to describe interactional constraints, which may or may not depend on the affinity variable (Sorsana \& Musiol, 2005; Sorsana \& Trognon, 2011; Trognon et al., 2008). We can summarize the interlocutory characteristics that play a structuring role within successful dyads ${ }^{13}$ to perform a complex cognitive task as follows. First, whatever the type of dyad, the child who begins the transaction is often the child who ends it, taking an action decision. This characteristic is related to the dynamics of any interaction: the cognitive activity of the partner who proposes an idea certainly takes precedence over the other interlocutor's cognitive activity, as the initial speaker is strongly engaged in the outcomes of that initial illocution, and the production of part of their thinking. This social and cognitive position commits (or obliges) the initial speaker to trying to establish a successful conclusion.

Second, there can be interactional constraints that depend on the affinity variable and differentially structure exchanges related to action. From a structural level, children sharing positive relationships (i.e., affine dyads) build verbal exchanges in which each child is very attentive to obtain the partner's agreement. By contrast, children sharing negative relationships (i.e., non-affine dyads) do not look for agreement, and impose their own decision. From a pragmatic level, within the affine dyads, the children confirm (or discuss) the suggested point of view, before one of them decides to do something; the decision to act is thus distributed. By contrast, within the non-affine dyads, the children are not concerned with expressing their point of view to their partners, as they seem to want to act on their own. The experimenter therefore has to remind them of the rules of the game. Finally, from a metacommunicational level, within the affine dyads, we observed a convergence of the expressed points of view, at the same time shared and mutually controlled. By contrast, within the non-affine dyads, the expression of power seems to be a priority instead of the joint production of knowledge.

Characteristics of the Disagreements That May or May Not Favour the Emergence of Creative Thinking

Looking at the characteristics of the disagreements between children (from 6- to 10-year-olds) in problem solving studies (Gilly \& Deblieux, 1999; Psaltis \& Duveen, 2007; Sorsana, 2003; Sorsana \& 
Musiol, 2005; Trognon et al., 2008), interlocutory analyses allowed researchers to identify the specificities of the disagreements that may produce creative ideas, compared to those that may not. When a creative idea emerges within dyads working on a cognitive task, we observed that the children express implicit disagreement, with various modes of expression: (a) behaviours (head movements, deictic gestures or body leaning towards another object); (b) asking for justifications (modulating the force of the request: "why?," "why was it more significant to say ...?"); (c) direct expression of disagreement using an attenuating expression ("yes ... but I don't want to ...," "I don't believe it's significant ...") or using deontic arguments with explicit reference to the instructions ("we're not allowed," "it's necessary"). They also build verbal exchanges based on a question/answer structure and are engaged in symmetrical interventions (e.g., proposition/proposition, where the partner aligns their proposition with that of their partner). By contrast, when dyads fail to produce creative ideas, we observed that the children express explicit disagreement, with various modes of expression: (a) direct formulation ("no," "oh no," "but no," ...); (b) orders (many imperative illocutions); (c) imposing own choice of action; (d) interrupting the partner's utterance or action. Additionally, there is a prevalence of the literal meaning of speech acts, an absence of the basic question/answer structure, and no or little change of (high) position in the management of the social relationships (i.e., it is the same child who utters a proposition and/or makes an action).

As illustrated above, pragmatic analyses of interactions, particularly conversational ones, allow researchers to work on a temporal scale, highlighting the unfolding of sociocognitive behaviours in considerable detail and in all their complexity. From the interlocutors' point of view, the conversation is a kind of helped introspection ${ }^{14}$, where they have to think together about solving a complex problem. From the analyst-researcher's point of view, the undeniable advantage of formalizing verbal interactions is that it goes beyond ad hoc analyses and allows for the comparison of situations favouring cognitive development. Formalization makes it possible to infer whether a given performance or response to a problem (a) belongs to a single speaker who offers it to their partner, or improves it via the catalyst of interaction; (b) has premises identifiable in one speaker's talk, which grew up richer thanks to the partner's proposals, assumptions, and objections; or (c) emerges in a new and creative way within the conversational space, and more generally within the talk-together event; these nascent ideas cannot be discerned in the initial actions or utterances. Logical tools provide formal analyses that allow us to infer the most probable reasoning paths. The properties of the sequential order of interaction contribute to the drawing of these inferences. Moreover, ethnomethodological studies have demonstrated that it is the conversational flow itself that controls the interlocutors' interpretations and offers analyst-researchers the best means of identifying the partners' inferences and interpretations. But how can we be sure that the reasoning paths we discern are truly those that are followed by the interlocutors? In order to go thoroughly into the understanding of the reasoning paths actually accomplished between children in a given problem-solving situation, in the next and last section we will advocate to combine the interlocutory analyses of conversations with a technique of interview which allows us to have access to the point of view of the children themselves concerning the actions they made: the explicitation interview.

\section{Cross-Referencing Third-Person and First-Person Analyses}

Our methodological recommendation consists in coupling pragmatic analyses of conversation with analyses of the experiences reported by each of the children engaged in a joint problem-solving exercise. An explicitation interview (Vermersch, 1994, 2009, 2012) allows adults as well as children to report the course of their mental actions in a specified situation. We assume that a cognitive advance inferred by analyst-researchers can thus be checked against the participants' own accounts. In other words, the goal is to cross-reference observations of the partners' behaviours and logics (third-person accounts) with the participants' own thoughts about their actions and logics (first-person accounts ${ }^{15}$ ).

\section{Interviewing the Lived Experience Associated with the Emergence of Fresh Knowledge}

The explicitation interview was elaborated by Vermersch $(1994,2009,2012)$, following the Piagetian theorization of the role of action on cognitive development (Piaget, 1926, 1974a, b). An 
explicitation interview serves to guide the interlocutors' introspection, prompting them to describe their past activity in order to find out what they actually did. The purpose is to have access to non-conscious information, either due to implicit and automated actions, or due to not yet elaborated and conscious actions. It therefore refers to acts performed at a precise point in the interviewees' lived experience, focusing their attention on precise aspects of their actions, and referring to evocative memory (i.e., involuntary, predeliberate memory that refers to the lived experience). The interviewer creates the conditions for the person to remember, without injunction to remember; the interviewee takes the time to let a precise moment come back with pictures, sounds, smells, feelings, thoughts; becoming in a posture of evocation means that the interviewee is more present to this past lived situation than to the current situation of the interview, thanks to evocative memory (also called "passive memory" or "concrete memory"). It is a memory related to the personal and sensory experience associated with precise events lived at a specific moment and place. This kind of interview has an iterative structure (i.e., the interviewer helps the interviewees to recall their past experience several times and to explore particular moments in this lived experience in detail). The interviewer must take care not to induce ideas or false memories, and be fully aware of the potential perlocutory impact of their illocutions. The technique can be summarized in four main points: (a) guiding "the recall process towards a specified situation"; (b) guiding it "towards sensory evocation, where the subject themself provides the modality and contents"; (c) avoiding "any direct voluntary research of the content of the recall"; (d) ensuring "guidance with a subtle enough fractioning" of the different steps of action (Vermersch, 1994, pp. 72-73). These main points will be developed and illustrated from an adult/child excerpt (Thabuy, 2014) in the next section.

What happens when a new idea emerges in an individual's mind? Petitmengin $(1999,2007,2016)$ and Petitmengin and Bitbol (2009) studied the lived experience associated with the emergence of a new idea, in particular using the explicitation interview. Her detailed analyses of the microdynamics of the ideation processes are an additional illustration of the embodiment of human thinking (Varela et al., 1991). All the testimonies collected from adults have the following main characteristics (Petitmengin, 1999, 2007, 2016): the emergence of a new idea is not the result of a deductive or discursive process; the new idea often appears unexpectedly - as a blurred and fuzzy feeling which takes time to mature - and unfurls in a bodily and gestural experiential dimension. These testimonies describe a transfer of attention from mind to body. This attention becomes panoramic, allowing individuals to describe the intensity, direction, or pace of their felt meaning. Petitmengin (2016) used the analogy of the feelings we experience when listening to music: the emergent idea has texture, density, and rhythm, and can be described as an inner landscape, just like the space that unfurls when we are listening to music. This author linked these lived experiences of the emergence of a new idea to (a) the transmodal and rhythmic characteristics of the world experienced by infants (Stern, 1989) as well as to (b) the sensorimotor schemata defined as the primitive and transmodal structures of our experience of the world (Lakoff \& Johnson, 1999, but see also Piaget's works).

Our proposal to cross-reference first-person and third-person accounts to study how fresh knowledge emerges from the activity of thinking in a joint problem-solving situation can be likened to the enaction research program developed by Varela; more precisely, our proposition falls within the neurophenomenological research program in the broad sense ${ }^{16}$ as we will argue below. Every scientific experiment relies on reports of the participants' experience in one way or another (verbalizations via scales, questionnaires, or interviews) to establish correlations between the evaluation of behaviours (or neurophysiological events) and first-person testimony. According to Bitbol (2006, pp. 148-149), Varela

fully takes into account this methodological feature, as neglected as it is universal. However, in contrast to other researchers who implement it in an unwise way, he seeks to take it to its maximum effectiveness, and above all productivity. The challenge is therefore to reinforce the circulation between the two sectors of knowledge (first person and third person). We should not be satisfied to raise concomitances that remain approximate in many ways as long as neither the quality of the subjective experience, its stability, nor the reliability of its report are up to the neurophysiological data. The simple report of concomitance needs to be replaced by 'mutual constraints' (Varela, 1996). 
As stressed by Varela (1997, cited by Bitbol, 2006), these mutual constraints must build a bridge between the subjective and objective levels, with two-way circulation between them that is operationally generative. The three conditions under which it is possible to establish these mutual constraints and make them operationally generative are described in Depraz et al. (2003). They are (Bitbol, 2006): (a) cultivating the stability and reproducibility of the contents of the subjective experience via phenomenological reduction methods; (b) developing the reliability of the reporting of experience via explicitation interview techniques; (c) improving the circulation of mutual constraints between expressions in the first person and descriptions in the third person, in order to increase their generativity.

Let us clarify in what sense our proposal is in line with the neurophenomenological research program elaborated by Varela (1996) and Varela et al. (1991). If the neurophenomenological program consists in building meaningful bridges between contemporary cognitive sciences and "a disciplined approach to human experience" permitted by phenomenology, our own research on cognitive development is not at the level of the molecules and neurons. Nevertheless, we also aim at building a "fertile dialogue," by comparing what we understand about cognitive development from procedural and conversational analyses of specific joint problem-solving interactions (our third-person analysis level) with what we will discover from children's lived and direct experience analyses, guided with an explicitation interview (firstperson analysis level). Following Varela (1996), we hope to reach a "stereoscopic perspective" of the children's cognitive activities. We became receptive to the idea that "any science of cognition and mind must, sooner or later, come to grips with the basic condition that we have no idea what the mental or the cognitive could possibly be apart from our own experience of it" (Varela, 1996, p. 331). Thus, as Varela (1996) suggests, by considering the co-determination of these two kinds of accounts we will be able to explore the bridges, the challenges, the outlines, and the contradictions between them. Such a position commits us to also conceive that the two fields of phenomena that we apprehend in first person and in third person "have equal status in demanding a full attention and respect for their specificity" (Varela, 1996, p. 343). The first-person accounts will be useful both to approach the lived experience of these joint reflexive and problem-solving activities and to provide "constraints on empirical observations." Finally, these backward and forward moves between third-person and first-person analyses may lead us to more deeply examine one of the potential cognitive paths inferred by the analyst-researcher. The neurophenomenological hypothesis according to which "both accounts be mutual constraints on each other" (Varela, 1996, p. 344) appears very stimulating because it will force us to better account for the lived experience of young protagonists solving a problem jointly. How can we proceed?

Researchers now have a very detailed analysis procedure at their disposal (Petitmengin et al., 2019; Valenzuela-Moguillansky \& Vásquez-Rosati, 2019), and the explicitation interview is an important part of the toolbox used in the micro-phenomenological approach ${ }^{17}$ to studying subjective experience (OllagnierBeldame \& Cazemajou, 2019). This procedure takes a past lived experience and uses it as a reference (called V1; in French vécu de référence; Vermersch, 2012). This experience becomes the topic of an introspective description that constitutes a second lived experience (called V2; in French vécu d'explicitation; Vermersch, 2012). The latter differs from the former, as it is a lived experience of explicitation; an introspection based on the evocation of V1. For example, if we want to study how children memorize a poem, we ask them to evoke a specific moment (V1) when they were engaged in the activity of learning the poem by heart. We then conduct an explicitation interview to help the children say how they concretely memorized this poem (V2). In other words, the purpose is to describe this past lived activity, engaging in introspection and verbally describing how they went about memorizing the poem. However, simply asking people for a description does not mean that they will give one. To do so, they may require guidance. The interviewer must focus entirely on the succession of micro-actions making up this activity, and not on the content of the activity. In other words, the interviewer must focus on the "temporal unfolding that organizes the precise description of the activity" (Vermersch, 2012, p. 122). The analysis procedure can be broken down into several stages. Valenzuela-Moguillansky and Vásquez-Rosati (2019), for instance, described a 15-stage procedure that we do not reproduce here. 


\section{Can Children Be Capable of Describing Their Subjective Experience?}

At first elaborated for guiding adults, the explicitation interview is used with children in school settings (Maurel, 2009; Thabuy \& Maurel, 2014) ${ }^{18}$. Thabuy and Maurel (2014) have provided several examples (with full transcriptions and detailed analyses) of explicitation interviews with young children in nursery or primary school. The youngest child was 5 years old, and all the children produced very elaborate descriptions of subjective experiences associated with specific cognitive obstacles. All these examples offer methodological tools for using explicitation interviews with children. For instance, in the case study reported by Thabuy (2014), Karim is a 6-year-old pupil with reading difficulties. Sometimes he produces aberrant sentences. The question is "What is Karim doing when he writes these strings of incomprehensible letters?" The initial speech turns in the explicitation interview conducted by Thabuy (2014, pp. 34-35) were as follows:

Adult 1: OK, Karim, if you agree, we will look back at what happened a few moments ago when I asked you to write the sentence "Mum buys a house." You were sat at your table, you had your pencil in your hand, and your book was open in front of you, there were a lot of things written on the page. Can you remember that moment?

Karim 2: Yes.

A3: When I gave you the sentence "Mum buys a house," what happened for you at that point, when you heard this sentence?

K4: "Mum," I knew I had to write "mum," then, “mum," I knew it, I knew it, I wrote "mum" because I knew it.

A5: And after that, what did you do?

K6: After that, I remembered that the sentence was "mum buys," I looked for the word "buys," I looked for it on the page where I knew it was written.

A7: And after that?

K8: After that, I had to write "a house," and then at that point, I screwed my eyes tight shut.

A9: And when you screwed your eyes tight shut what happened for you? [Karim glances up]

K10: Well, when I screw my eyes tight shut like that, well, everything becomes white in my head.

A11: Ok, and then, when it's white like that in your head, what happens?

K12: Above, it's written. In my head, it's written on white.

$[\ldots]$.

This excerpt allows us to comment the main points of the explicitation interview technique (Vermersch, 1994).

\section{Guiding the Recall Process towards a Specified Situation}

First of all, the interviewer and the interviewee have to accept a communication contract specifying the objectives really at stake in the interview. Usually, the initial sentence is a proposition formulated as follows: "I propose, if you agree, that you take the time to let the moment come back where X happened," as uttered by the adult (A1) in the case study. Then, the adult (A1, A3) helped the child retrieve the sensory context in which he was asked to write "Mum buys a house," and wrote "Mum buys deche." To guide the recall process towards this specific situation, the interviewer accurately contextualized this moment ("You were sat at your table, you had your pencil in your hand, and your book was open in front of you, there were a lot of things written on the page ..." $)^{19}$.

\section{Guiding the Recall Process towards Sensory Evocation}

To guide the interviewee towards the evocation posture (also called "embodied posture of speech"; Ollagnier-Beldame \& Cazemajou, 2019), the interviewer may (a) slow down the interviewee's speech, speaking themself more slowly, (b) formulate sensory questions that favour the interviewee's selfreflections about their activity ("what did you see ... hear ... smell ...?," "How was this sound you heard ...?"). In the case study, the questioning is (A3): "When I gave you the sentence 'Mum buys a house,' what happened for you at that point, when you heard this sentence?"

Verbal and non-verbal criteria allow the interviewer to detect the subject's evocation posture, as it is noticed in the excerpt (A9): Karim displayed signs indicating that he had returned to the spatiotemporal 
and sensory context of the lived experience, and relived this situation in his mind. At A9, he glanced up, after which his sentences were uttered in the present indicative.

\section{Avoiding Any Direct Voluntary Research of the Content of the Recall}

"Why" questions are not used because the interviewer does not seek after the interviewee's comments on their actions. Rather, "how" and "what" questions are favoured because they encourage the interviewee to give information about what they perceived and acted. To illustrate that point, let us see the case study when the adult guided Karim using a series of similar and non-inductive questions (A9, A11): "And when you (+ verb of action) what happens?"

\section{Ensuring Guidance with a Subtle Enough Fractioning of the Different Steps of Action}

Different levels of describing the actions of a specific moment exist, and two temporal dimensions of the experience are explored. First, the diachronic dimension corresponds to the way in which the different steps of action follow on from each other. To give rise to it, the interviewer may formulate the following questions: "What did you begin to do?," "And how did you do?," "And then, what happens?," "How do you know that it is the right word?," and so forth. Then, each step of action can be fine-grained described, namely in a synchronic dimension: the interviewee is guided to become aware of "all that happens at the same time in the cognitive, perceptive, attentional, bodily, sensory, and affective dimensions" (OllagnierBeldame \& Cazemajou, 2019, p. 414).

Step by step, Karim was thus able to describe his different actions during this specific past experience of writing. He explained how he wrote the right words and the wrong word, and how he was now able to correct the wrong word ("deche") by writing the right one ("a house").

Presentation of an Exploratory Research Design for Interviewing Children and Cross-Referencing Third-Person and First-Person Analyses of the Emergence of Fresh Knowledge

As illustrated above, children can become aware of their lived experience, even at the earliest ages. Following the assumption according to which social interaction organizes the contents of thought and even structures the operations of thinking, we challenge to explore and promote another methodology - not used in the historico-cultural developmental field yet - likely to capture new social clues of such structuring impact on children's cognitive activities when they describe their own lived experience of coworking.

\section{Research Questions}

The objective of this explorative design is twofold: first, to compare the results of the first-person and third-person analyses led in parallel (see below the three stages of our design), and to explore the bridges, the challenges, the outlines, and the contradictions between these two kinds of accounts considered as co-determined, in line with Varela's idea (1996) previously mentioned; and second, to detect testimonies of the potential role of social interaction in these children's movements of thinking in the problem-solving situation.

\section{Participants and Materials}

In order to begin such an empirical research exploration and to favour the children's awareness of the impact of social interactions on their own behaviours, participants would be 10-year-old children interacting with a friend in a problem-solving situation. According to Selman $(1980,1981)$, from around this age, intimate and mutually shared relationships are established, and children become accurately aware of the impact of their respective behaviours on their social relationships. Moreover, linguistic and pragmatic skills improve with age (Hwa-Froelich, 2014; Owens, 2012), and 10-year-old participants would be easier to interview by interviewers recently trained to use the explicitation interview technique. Later studies could explore this topic with younger children, since works in school settings have shown elaborate descriptions of subjective experiences produced by pupils as young as 5 years of age. 
The recommended task would be one item taken from Raven's Standard Progressive Matrices (Raven et al., 1998). Such a task does not take much time to be jointly solved. Moreover, unlike the Tower of Hanoi task ${ }^{20}$ for example, this task does not need anticipation and planning sequences to be solved. So, it seems appropriate for guiding the recall process towards a specified situation, stabilizing the recall of the specified moment, and guiding it towards sensory evocation.

\section{Recommended Methods}

Children would be invited to solve one item taken from Raven's Standard Progressive Matrices (Raven et al., 1998) in dyads. They would then individually undergo an explicitation interview enabling them to describe their experience of the emergence of ideas in conversation.

The design would feature three stages:

(1) Dyads of children are invited to jointly solve the Raven's item; this problem-solving situation is videotaped.

(2) The two children watch the resulting video and identify a specific cognitive difficulty they both had to deal with.

(3) An individual explicitation interview focuses on that specific cognitive difficulty (first-person analyses).

\section{Recommended Data Analysis}

Two transcriptions precede the two following kinds of data analyses. The children's conversation transcripts when they are processing the Raven's item aim at describing and formalizing simultaneously their emerging reasoning (i.e., the propositional contents of their utterances and their actions) as well as the social and emotional relations that circulate within conversations. The analyst-researcher would adopt an interlocutory analysis (i.e., third-person analysis). The general procedure to analyse the children's conversations would be divided in two stages (Trognon et al., 2011c). A first stage consists in descriptive analyses. We consider the corpus transcription as a succession of utterances (or statements) that are linked with the others by a relation based on pragmatic and logical rules, which are constitutive of a specific game of dialogue that we have to identify (Trognon et al., 2010, 2011b). More precisely, this step consists in breaking up these statements, using the table of interlocutory analysis (Table 1).

The questions would be (a) to identify the literal speech acts ${ }^{21}$ that structure the sequential organization of the partners' verbal behaviours (see the "illocutory goal" column); (b) to locate the stakes of these statements, from the principle of co-operation (Grice, 1975) (i.e., statements that are interpretable like adjacent statements: question/answer, invitation/refutation, etc., and that are called "inter-statements relations" in the another column); and (c) to describe the cognitive movements conveyed in the propositional contents of the speech acts $[\mathrm{F}(\mathrm{p})]$ (see the "propositional content" column). This first step corresponds to the description of the analyst-researcher's intuitions related to the course of the various ideas formulated between the interacting speakers. To do so, the analyst-researcher would base their analyses on the sequentiality of the conversation, in order to mark out the path of their implicit cognitive and social analyses. To sum up, we first consider the children's speech as an emerging phenomenological event. A second stage is based on demonstrations that allow the analyst-researcher to infer the probable communicative and cognitive progression that lead to an agreement (or a disagreement) about a joint decision of a solution. More precisely, we recommend formalizing the emergence of a sociocognitive solution (or conflict) in natural language, i.e., representing the inferential movements (or thinking processes) from the linguistic and cognitive operations, which are subjacent with the resolution of the Raven's item. Can we infer the crucial social and cognitive moment in the process leading to the solution?

The transcripts of each child's subjective account of their own past experience of jointly solving the Raven's item, as they are guided with an explicitation interview, aim at (a) describing step by step how the 
specified cognitive difficulty (they both had to deal with) emerged; (b) finding out how child A (then child B) overcame this obstacle (thanks to an idea/cognitive lead/intuition that appears to solve the problem) and describing how it occurred; and (c) finding evidence of the potential role of social interaction in the children's movements of thinking to overcome the cognitive obstacle: attention should be paid to any testimony of social and relational features likely to have influenced the logic of the child's action. The general procedure to analyse these experiential interviews should be broken down into several stages, as developed by Vermersch $(2012)^{22}$ and studied thoroughly by Valenzuela-Moguillansky and VásquezRosati (2019): fifteen stages are organized into five sections allowing the tracing of the analyst's criteria in the process of building structures of experience. The five sections are: (a) data preparation, (b) specific diachronic analysis, (c) specific synchronic analysis, (d) generic diachronic analysis, and (e) generic synchronic analysis ${ }^{23}$. "Doubts or issues that may arise during the analysis and criteria used to solve them are also noted at each stage" (Valenzuela-Moguillansky \& Vásquez-Rosati, 2019, p. 125).

Finally, we recommend comparing the results yielded by these two kinds of analyses in order to find convergences and differences in the descriptions of the children's reasoning mode. In other words, the challenge is to articulate the logico-linguistic formalism provided by the analyst-researcher with the children's reported subjective experience of their own cognitive activity.

\section{Conclusion}

Based on the empirical study of the structure and content of conversation, researchers can infer how individuals (a) co-build local models, in order to understand and interpret the situation in which they find themselves, (b) co-build the goals and subgoals of a cognitive problem, and (c) cooperate (or not). However, how can we unequivocally identify the key cognitive-conversational events? How can we locate the sociocognitive event, analysed from the procedures and content of the conversation, amidst all the parameters involved in the development of a new idea or creative solution? Our proposal to cross-reference two methodologies for studying cognitive activity seems a promising way of bridging the gap between levels of analysis that are often separated, namely the objective and subjective levels of collecting and analysing data. In addition, this proposal contributes to the growing interest in the analysis of lived subjective experience as a resource for education and training (Bocchi \& Damiano, 2013; Iannaccone \& Cattaruzza, 2017). We believe that the issue at stake is to find new empirical indices that allow us to understand better how and through which cognitive processes the social aspect influences interactions. By combining analyses of cognitive activities performed in specific problem-solving situations, in both the third and first person, we will contribute to the debate about intersubjective cognition.

\section{Acknowledgement}

I would like to thank Elizabeth Wiles Portier for comments on the English style (of the first version of this paper) as well as the two anonymous reviewers for constructive criticism on the article.

\section{Statement of Ethics}

All procedures performed in studies involving human participants were in accordance with the ethical standards of the institutional and/or national research committee and with the 1964 Helsinki declaration and its later amendments or comparable ethical standards.

\section{Conflict of Interest Statement}

The author declares that she has no conflict of interest.

\section{Funding Sources}

This study was not funded.

\section{References}

Austin, J. L. (1962). How to do things with words. Oxford University Press. 
Azmitia, M., \& Montgomery, R. (1993). Friendship, transactive dialogues, and the development of scientific reasoning. Social Development, 2(3), 202-221. https://doi.org/10.1111/j.1467-9507.1993.tb00014.x

Baker, M. (2009). Argumentative interactions and the social construction of knowledge. In N. Muller Mirza \& A.N. Perret-Clermont (Eds.), Argumentation and education. Theoretical foundations and practices (pp. 127144). Springer. https://doi.org/10.1007/978-0-387-98125-3_5

Bernicot, J., Trognon, A., Guidetti, M., \& Musiol, M. (Eds.). (2002). Pragmatique et psychologie [Pragmatics and psychology]. Presses Universitaires de Nancy.

Bitbol, M. (2006). Une science de la conscience équitable. L'actualité de la neurophénoménologie de Francisco Varela [A science of the equitable consciousness. The current Francisco Varela's neurophenomenology]. Intellectica, 1(43), 135-157. https://doi.org/10.3406/intel.2006.1340

Bocchi, G., \& Damiano, L. (2013). The enactive mind. An epistemological framework for radically embodied didactics. Education Sciences \& Society, 1, 113-134.

Bruner, J. S. (1986). Actual minds, possible worlds. Harvard University Press.

Bruner, J. S. (1990). Acts of Meaning. Harvard University Press.

Bruner, J. S. (1996). The culture of Education. Harvard University Press.

Corsaro, W. A. (1997). The sociology of childhood. Pine Forge Press.

Danis, A., Schubauer-Leoni, M. L., \& Weil-Barais, A. (2003). Interaction, acquisition des connaissances et développement [Interaction, knowledge, and development]. Bulletin de Psychologie, 56(4), 451-455.

Depraz, N., Varela, F. J., \& Vermersch, P. (2003). On becoming aware: A pragmatics of experiencing. John Benjamins Publishing. https://doi.org/10.1075/aicr.43

Doise, W. (1986). Levels of explanation in social psychology. Cambridge University Press.

Doise, W., Mugny, G., \& Perret-Clermont, A. N. (1975). Social interaction and the development of cognitive operations. European Journal of Social Psychology, 5(3), 367-383. https://doi.org/10.1002/ejsp.2420050309

Domberg, A., Köymen, B., \& Tomasello, M. (2018). Children's reasoning with peers in cooperative and competitive contexts. British Journal of Developmental Psychology, 36(1), 64-77. https://doi.org/10.1111/bjdp.12213

Dutilh Novaes, C. (2018). The enduring enigma of reason. Mind \& Language, 33(5), 513-524. https://doi.org/10.1111/mila.12174

Eerdmans, S. L. (2003). A review of John J. Gumperz current contributions to interactional sociolinguistics. In S. L. Eerdmans, C. L. Prevignano, \& P. J. Thibault (Eds.), Language and interaction. Discussion with John J. Gumperz (pp. 85-103). John Benjamins Publishing. https://doi.org/10.1075/z.117.08eer

Felton, M., \& Kuhn, D. (2001). The development of argumentative discourse skills. Discourse Processes, 32(2), 135153. https://doi.org/10.1080/0163853X.2001.9651595

Garfinkel, H. (1967). Studies in ethnomethodology. Prentice Hall.

Ghiglione, R., \& Trognon, A. (1993). Où va la pragmatique? De la pragmatique à la psychologie sociale [What is pragmatics coming to? From pragmatics to social psychology]. Presses Universitaires de Grenoble.

Gilly, M. (1989). The psychosocial mechanisms of cognitive constructions: Experimental research and teaching perspectives. International Journal of Education Psychology, 6(6), 607-621. https://doi.org/10.1016/08830355(89)90044-X

Gilly, M. (1991). Social psychology of cognitive constructions: European perspectives. In M. Carretero, M. Pope, S. Robertjan, \& J. L. Pozo (Eds.), Learning and instruction. European Research in an International Context (Vol. III, pp. 99-123). Pergamon Press.

Gilly, M. \& Deblieux, M. (1999). Analyse des médiations langagières en situation dyadique de résumé de récit [Analysis of language mediations within dyads of children summarizing narratives]. In M. Gilly, J.-P. Roux, \& A. Trognon (Eds.), Apprendre dans l'interaction: analyse des médiations sémiotiques [Learning in social interaction: Analysis of semiotic mediations] (pp. 95-120). Presses de l'Université de Provence \& Presses Universitaires de Nancy.

Gilly, M., Roux, J.-P., \& Trognon, A. (Eds.). (1999). Apprendre dans l'interaction. Analyse des médiations sémiotiques [Learning in social interaction. Analysis of semiotic mediations]. Presses de l'Université de Provence \& Presses Universitaires de Nancy.

Goffman, E. (1967). Interaction ritual: Essays in face-to-face behavior. Aldine.

Goodwin, C. (2000). Action and embodiment within situated human interaction. Journal of Pragmatics, 32(10), 1489-1522. https://doi.org/10.1016/S0378-2166(99)00096-X

Goodwin, C. (2007). Participation, stance and affect in the organization of activities. Discourse \& Society, 18(1), 53-73. https://doi.org/10.1177/0957926507069457

Greenfield, P., \& Lave, J. (1982). Cognitive aspects of informal education. In D. A. Wagner \& H. W. Stevenson (Eds.), Cultural perspectives on child development (pp. 181-207). Freeman. 
Grice, H. P. (1975). Logic and conversation. In P. Cole \& J. L. Morgan (Eds.), Syntax and semantics (pp. 41-58). Academic Press. https://doi.org/10.1163/9789004368811_003

Grice, P. H. (1989). Studies in the way of words. Harvard University Press.

Harris, P. L., \& Núñez, M. (1996). Understanding of permission rules by preschool children. Child Development, 67(4), 1572-1591. https://doi.org/10.2307/1131719

Heritage, J. C. (1984). Garfinkel and ethnomethodology. Polity Press.

Heritage, J. (1990). Interactional accountability: A conversation analytic perspective. In B. Conein, M. de Fornel, \& L. Quéré (Eds.), Les formes de la conversation (Vol. 8-1, pp. 23-50). CNET. https://doi.org/10.3406/reso.1990.3529

Hinde, R. A., Perret-Clermont, A. N., \& Stevenson-Hinde, J. (Eds.). (1985). Social relationships and cognitive development. Clarendon Press.

Hwa-Froelich, D. A. (2014). Social communication development. In D. A. Hwa-Froelich (Ed.), Social communication development and disorders (pp. 108-137). Psychology Press. https://doi.org/10.4324/9781315735627-5

Iannaccone, A., \& Cattaruzza, E. (2017). Le vécu subjectif dans la recherche en psychologie. Considérations théoriques et méthodologiques [The subjective lived experience in psychological research. Theoretical and methodological considerations]. Recherche et Formation, 80(80), 77-90. https://doi.org/10.4000/rechercheformation.2506

Karlsson, M., Hjörne, E., \& Evaldsson, A. C. (2017). Preschool girls as rule breakers: Negotiating moral orders of justice and fairness. Childhood, 24(3), 396-415. https://doi.org/10.1177/0907568216678292

Kendon, A. (1995). Gestures as illocutionary and discourse structure markers in Southern Italian conversation. Journal of Pragmatics, 23(3), 247-279. https://doi.org/10.1016/0378-2166(94)00037-F

Kerbrat-Orecchioni, C. (1996). La conversation [The conversation]. Seuil.

Köymen, B., \& Tomasello, M. (2018). Children's meta-talk in their collaborative decision making with peers. Journal of Experimental Child Psychology, 166, 549-566. https://doi.org/10.1016/j.jecp.2017.09.018

Kyratzis, A. (2004). Talk and interaction among children and co-construction of peer groups and peer culture. Annual Review of Anthropology, 33(1), 625-649. https://doi.org/10.1146/annurev.anthro.33.070203.144008

Kyratzis, A., \& Ervin-Tripp, S. M. (1999). The development of discourse markers in peer interaction. Journal of Pragmatics, 31(10), 1321-1338. https://doi.org/10.1016/S0378-2166(98)00107-6

Kyratzis, A., \& Jean Johnson, S. (2017). Multimodal and multilingual resources in children's framing of situated learning activities: An introduction. Linguistics and Education, 41, 1-6. https://doi.org/10.1016/j.linged.2017.07.002

Kyratzis, A., Ross, T. S., \& Köymen, S. B. (2010). Validating justifications in preschool girls' and boys' friendship group talk: Implications for linguistic and socio-cognitive development. Journal of Child Language, 37(1), 115-144. https://doi.org/10.1017/S0305000908009069

Lakoff, G., \& Johnson, M. (1999). Philosophy in the flesh. The embodied mind and its challenge to Western thought. Basic Books.

Larrue, J., \& Trognon, A. (1993). Organization of turn-taking and mechanisms for turn-taking repair in a chaired meeting. Journal of Pragmatics, 19(2), 177-196. https://doi.org/10.1016/0378-2166(93)90087-6

Lave, J. (1988). Cognition in practice. Mind, mathematics and culture in everyday life. Cambridge University Press. https://doi.org/10.1017/CBO9780511609268

Lave, J., \& Wenger, E. (1991). Situated learning: legitimate peripheral participation. Cambridge University Press. https://doi.org/10.1017/CBO9780511815355

Manes Gallo, M. C., \& Vernant, D. (1997). Pour une réévaluation pragmatique de l'assertion [Claims for revising the pragmatic status of assertion]. Psychologie de l'Interaction, II(1\&2), 7-41.

Maturana, H. R., \& Varela, F. J. (1992). The tree of knowledge. The biological roots of human understanding. Shambhala Publications.

Maurel, M. (2009). The explicitation interview: Examples and applications. Journal of Consciousness Studies, 16(10-12), 58-89.

Mercer, N. (2000). Words \& minds. How to use language to think together. Routledge. https://doi.org/10.4324/9780203464984

Mercier, H., \& Sperber, D. (2011). Why do humans reason? Arguments for an argumentative theory. Behavioral and Brain Sciences, 34(2), 57-74. https://doi.org/10.1017/S0140525X10000968

Moeschler, J. (1985). Argumentation et conversation [Argumentation and conversation]. Hatier.

Moeschler, J. (1993). Relevance and conversation. Lingua, 90(1-2), 149-171. https://doi.org/10.1016/0024$3841(93) 90065-5$ 
Mondada, L. (2004). Context and situation. In O. Houdé, D. Kayser, O. Koening, J. Proust, \& F. Rastier (Eds.), Dictionary of cognitive science. Routledge/Taylor \& Francis. Psychology Press. (Original work published 1998)

Mugny, G., \& Doise, W. (1978). Socio-cognitive conflict and structure of individual and collective performances. European Journal of Social Psychology, 8(2), 181-192. https://doi.org/10.1002/ejsp.2420080204

Mugny, G., Perret-Clermont, A. N., \& Doise, W. (1981). Interpersonal coordinations and sociological differences in the construction of the intellect. In G. M. Stephenson \& J. H. Davis (Eds.), Progress in applied social psychology (Vol. 1, pp. 315-344). John Wiley \& Sons.

Muller Mirza, N., \& Perret-Clermont, A. N. (Eds.). (2009). Argumentation and education: Theoretical foundations and practices. Springer. https://doi.org/10.1007/978-0-387-98125-3

Núñez, M., \& Harris, P. L. (1998). Psychological and deontic concepts: Separate domains or intimate connection? Mind \& Language, 13(2), 153-170. https://doi.org/10.1111/1468-0017.00071

Ollagnier-Beldame, M., \& Cazemajou, A. (2019). Intersubjectivity in first encounters between healthcare practitioners and patients: Micro-phenomenology as a way to study lived experience. The Humanistic Psychologist, 47(4), 404-425. https://doi.org/10.1037/hum0000133

Olry-Louis, I., \& Soidet, I. (2008). Collaborative writing devices, types of co-operation, and individual acquisitions. European Journal of Developmental Psychology, 5(5), 585-608. https://doi.org/10.1080/17405620701859563

Owens, R. E., Jr. (2012). Language development. Allyn and Bacon. (Original work published 2001)

Perret-Clermont, A. N. (1993). What is it that develops? Cognition and Instruction, 11(3-4), 197-205. https://doi.org/10.1080/07370008.1993.9649020

Perret-Clermont, A. N. (2001). Psychologie sociale de la construction de l'espace de pensée [Social psychology of thinking space construction]. In J. J. Ducret (Ed.), Actes du colloque. Constructivisme: Usages et perspectives en éducation (Vol. I, pp. 65-82). Département de l'Instruction Publique: Service de la Recherche en Education.

Perret-Clermont, A. N. (2003). Thinking spaces of the young. In A.-N. Perret-Clermont, C. Pontecorvo, L. B. Resnick, T. Zittoun, \& B. Burge (Eds.), Joining society. Social interaction and learning in adolescence and youth (pp. 3-10). Cambridge University Press. https://doi.org/10.1017/CBO9780511616341.003

Perret-Clermont, A. N. (2015). The architecture of social relationships and thinking spaces for growth. In C. Psaltis, A. Gillespie, \& A.-N. Perret-Clermont (Eds.), Social relations in human and societal development (pp. 5170). Palgrave Macmillan. https://doi.org/10.1057/9781137400994_4

Perret-Clermont, A. N., \& Nicolet, M. (Eds.). (2001). Interagir et connaître: Enjeux et régulations sociales dans le développement cognitif [Interacting and knowing. Stakes and social regulations in cognitive development]. L'Harmattan. (Original work published 1988)

Petitmengin, C. (1999). The intuitive experience. In F. Varela \& J. Shear (Eds.), The view from within: First-person approaches to the study of consciousness (pp. 43-77). Imprint Academic.

Petitmengin, C. (2007). Towards the source of thoughts. The gestural and transmodal dimension of lived experience. Journal of Consciousness Studies, 14(3), 54-82.

Petitmengin, C. (2014). Comment on Vermersch's book "Explicitation et Phénoménologie." Journal of Consciousness Studies, 21(11-12), 196-201.

Petitmengin, C. (2016). The scientist's body at the source of meaning. In D. Schoeller \& V. Saller (Eds.), Thinking. Practicing radical reflection (pp. 28-49). Verlag Karl Alber.

Petitmengin, C., \& Bitbol, M. (2009). The validity of first-person descriptions as authenticity and coherence. Journal of Consciousness Studies, 16(10-11), 363-404.

Petitmengin, C., Remillieux, A., \& Valenzuela-Moguillansky, C. (2019). Discovering the structures of lived experience. Towards a micro-phenomenological analysis method. Phenomenology and the Cognitive Sciences, 18, 691-730. https://doi.org/10.1007/s11097-018-9597-4

Piaget, J. (1926). La représentation du monde chez l'enfant. Alcan. (Transl. in English: Piaget, J. (1929). The child's conception of the world. Harcourt, Brace and Co.).

Piaget, J. (1974a). La prise de conscience [The sudden awareness]. Presses Universitaires de France.

Piaget, J. (1974b). Réussir et comprendre. Presses Universitaires de France. (Transl. in English: Piaget, J. (1978). Success and understanding. Routledge \& Kegan Paul).

Politzer, G. (2004). Reasoning, judgment and pragmatics. In I. Noveck \& D. Sperber (Eds.), Experimental pragmatics (pp. 94-115). Palgrave. https://doi.org/10.1057/9780230524125_5

Politzer, G., \& Macchi, L. (2000). Reasoning and pragmatics. Mind \& Society, 1(1), 73-93. https://doi.org/10.1007/BF02512230 
Psaltis, C. (2011). From epistemic to the social-psychological subject: The missing role of social identities, asymmetries of status, and social representations. Commentary on Sorsana and Trognon. Human Development, 54(4), 234-240. https://doi.org/10.1159/000330299

Psaltis, C., \& Duveen, G. (2006). Social relations and cognitive development: The influence of conversation type and representations of gender. European Journal of Social Psychology, 36(3), 407-430. https://doi.org/10.1002/ejsp.308

Psaltis, C., \& Duveen, G. (2007). Conservation and conversation types: Forms of recognition and cognitive development. British Journal of Developmental Psychology, 25(1), 79-102. https://doi.org/10.1348/026151005X91415

Psaltis, C., Duveen, G., \& Perret-Clermont, A. N. (2009). The social and the psychological: Structure and context in the intellectual development. Human Development, 52(5), 291-312. https://doi.org/10.1159/000233261

Psaltis, C., Gillespie, A., \& Perret-Clermont, A. N. (Eds.). (2015). Social relations in human and societal development. Palgrave Macmillan. https://doi.org/10.1057/9781137400994

Raven, J. C., Court, J. H., \& Raven, J. (1998). Progressive Matrices Standard (PM38). Oxford Psychologists Press.

Rips, L. J. (1998). Reasoning and conversation. Psychological Review, 105(3), 411-441. https://doi.org/10.1037/0033-295X.105.3.411

Rogoff, B. (1990). Apprenticeship in thinking: cognitive development in social context. Oxford University Press.

Rogoff, B., \& Angelillo, C. (2002). Investigating the coordinated functioning of multifaceted cultural practices in human development. Human Development, 45(4), 211-225. https://doi.org/10.1159/000064981

Roulet, E. (1992). On the structure of conversation as negotiation. In H. Parret \& J. Verschueren (Eds.), On) Searle on conversation (pp. 91-99). John Benjamins Publishing. https://doi.org/10.1075/pbns.21.05rou

Roulet, E., Auchlin, A., Moeschler, J., Rubattel, C., \& Schelling, M. (1985). L'articulation du discours en français contemporain [The articulation of discourse in contemporary French]. Peter Lang.

Sacks, H., Schegloff, E. A., \& Jefferson, G. (1974). A simplest systematics for the organization of turn-taking for conversation. Language, 50(4), 696-735. https://doi.org/10.1353/lan.1974.0010

Saxe, G. B. (1988). The mathematics of child street vendors. Child Development, 59(5), 1415-1425. https://doi.org/10.2307/1130503

Saxe, G. B. (2002). Children's developing mathematics in collective practices: A framework for analysis. Journal of the Learning Sciences, 11(2), 275-300. https://doi.org/10.1207/S15327809JLS11,2-3n_6

Schegloff, E. A. (1991). Conversation Analysis and Socially Shared Cognition. In L. B. Resnick, J. M. Levine, \& S. D. Teasley (Eds.), Perspectives on socially shared cognition (pp. 150-171). American Psychological Association. https://doi.org/10.1037/10096-007

Schliemann, A. D., Carraher, D. W., \& Ceci, S. J. (1997). Everyday cognition. In J. W. Berry, P. R. Dasen, \& T. S. Saraswathi (Eds.), Handbook of cross-cultural psychology: Vol. 2. Basic processes and human development (pp. 177-216). Allyn and Bacon.

Schwarz, B., \& Baker, M. J. (2016). Dialogue, argumentation and education: History, theory and practice. Cambridge University Press. https://doi.org/10.1017/9781316493960

Searle, J. R. (1979). Expression and meaning. Cambridge University Press. https://doi.org/10.1017/CBO9780511609213

Searle, J. R., \& Vanderveken, D. (1985). Foundations of illocutionary logic. Cambridge University Press.

Selman, R. L. (1980). The growth of interpersonal understanding: Developmental and clinical analyses. Academic Press.

Selman, R. L. (1981). The child as a friendship philosopher. In S. R. Asher \& J. M. Gottman (Eds.), The development of children's friendships (pp. 242-271). Cambridge University Press.

Sorsana, C. (1999). Psychologie des interactions sociocognitives [Psychology of sociocognitive interactions]. A. Colin (Collection Synthèse).

Sorsana, C. (2003). Comment l'interaction coopérative rend-elle plus "savant"? Quelques réflexions à propos des conditions nécessaires au fonctionnement dialogique du conflit sociocognitif [How do cooperative interaction make us more erudite? Some reflections about the necessary conditions for dialogical functioning of the sociocognitive conflict]. Orientation Scolaire et Professionnelle, 32(3), 437-473. https://doi.org/10.4000/osp.3309

Sorsana, C. (2011). L'activité conversationnelle est-elle une fenêtre ouverte sur la pensée de soi et d'autrui? [Is conversational activity an open window on thinking about oneself and other?] Enfance, 63(1), 69-91. https://doi.org/10.4074/S0013754511001066

Sorsana, C., \& Musiol, M. (2005). Power and knowledge. How can rationality emerge from children's interactions in a problem-solving situation? In E. Grillo (Ed.), Power without domination. Dialogism and the empowering 


\section{property of communication}

https://doi.org/10.1075/dapsac.12.09sor

(pp. 161-221). John

Benjamins

Publishing.

Sorsana, C., \& Trognon, A. (2011). Contextual determination of human thinking: About some conceptual and methodological obstacles in psychology studies. Human Development, 54(4), 204-233. https://doi.org/10.1159/000329844

Sorsana, C., \& Trognon, A. (2018). Conversing as metaphor of human thinking: Is mind like a conversation? Integrative Psychological \& Behavioral Science, 52(2), 241-256. https://doi.org/10.1007/s12124-018-9424$\mathrm{z}$

Sperber, D., \& Wilson, D. (1995). Relevance: communication and cognition. B. Blackwell. (Original work published 1979)

Stern, D. N. (1989). Pre-reflexive experience and its passage to reflexive experience. In C. Petitmengin (Ed.), Ten years of viewing from within: The legacy of Francisco Varela (pp. 307-331). Imprint Academic.

Tartas, V., Baucal, A., \& Perret-Clermont, A.-N. (2010). Can you think with me? The social and cognitive conditions and the fruits of learning. In C. Howe \& K. Littletown (Eds.), Educational dialogues: Understanding and promoting productive interaction (pp. 64-82). Routledge.

Tartas, V., \& Perret-Clermont, A. N. (2008). Socio-cognitive dynamics in dyadic interaction: How do you work together to solve Kohs cubes? European Journal of Developmental Psychology, 5(5), 561-584. https://doi.org/10.1080/17405620701859522

Teasley, S. D. (1995). The role of talk in children's peer collaborations. Developmental Psychology, 31(2), 207-220. https://doi.org/10.1037/0012-1649.31.2.207

Thabuy, A. (2014). Accéder à la logique singulière d'un élève: Entretien avec Karim [Acceding to the peculiar logic of a pupil: interview with Karim]. In A. Thabuy and M. Maurel (Eds.), L'entretien d'explicitation avec de jeunes enfants [Explicitation interview with young children]. Expliciter, 3340.https://www.grex2.com/assets/files/Dossiers/Ede\%20avec\%20de\%20jeunes\%20enfants.pdf

Thabuy, A., \& Maurel, M. (2014). L'entretien d'explicitation avec de jeunes enfants [Explicitation interview with young children].

https://www.grex2.com/assets/files/Dossiers/Ede\%20avec\%20de\%20jeunes\%20enfants.pdf

Tomasello, M. (1999). The cultural origins of human cognition. Harvard University Press. https://doi.org/10.2307/j.ctvjsf4jc

Tomasello, M. (2014). A natural history of human thinking. Harvard University Press. https://doi.org/10.4159/9780674726369

Trognon, A. (1991). L'interaction en général: Sujets, groupes, cognitions, représentations sociales [Interaction in general: subjects, groups, cognitions, social representations]. ConneXions (Cupertino, Calif.), 57(1), 9-25.

Trognon, A. (1993). How does the process of interaction work when two interlocutors try to resolve a logical problem? Cognition and Instruction, 11(3-4), 325-345. https://doi.org/10.1080/07370008.1993.9649028

Trognon, A. (2001). Speech acts and the logic of mutual understanding. In D. Vanderveken \& S. Kubo (Eds.), Essays in speech act theory (pp. 121-133). John Benjamins Publishing. https://doi.org/10.1075/pbns.77.08tro

Trognon, A., \& Batt, M. (2010). Interlocutory logic: A unified framework for studying conversational interaction. In J. Streek (Ed.), New adventures in language and interaction (pp. 9-46). John Benjamins Publishing. https://doi.org/10.1075/pbns.196.02tro

Trognon, A., \& Batt, M. (2013). A new link in the Unification of the Sciences of Cognition (Commentary on Mercier: Using evolutionary thinking to cut across disciplines: The example of the argumentative theory of reasoning). In P. H. Crowley \& T. R. Zentall (Eds.), Comparative decision making (pp. 312-315). Oxford University Press. https://doi.org/10.1093/acprof:oso/9780199856800.003.0030

Trognon, A., Batt, M., Caelen, J., \& Vernant, D. (Eds.). (2011a). Logical properties of dialogue. Presse Universitaires de Nancy.

Trognon, A., Batt, M., \& Marchetti, E. (2011b). Le dialogisme de la rationalité dans l'ordre de l'interaction [The dialogism of rationality in the order of interaction]. Bulletin de Psychologie, 64(5), 439-455. https://doi.org/10.3917/bupsy.515.0439

Trognon, A., Batt, M., Schwarz, B. B., Perret-Clermont, A. N., \& Marro, P. (2003). L'apprentissage dans l'interaction. Essai de logique interlocutoire [Learning in social interaction. Essay of interlocutory logic]. In A. Herzig, B. Chaïb-Draa, \& P. Math (Eds.), Modèles formels de l'interaction. Actes des secondes journées francophones de Lille (pp. 229-240). Cepaduès.

Trognon, A., Batt, M., \& Sorsana, C. (2010). Apprentissage de la division en interaction: Analyse formelle des microchangements communicationnels et cognitifs [Learning division in social interaction: Formal analysis of the 
communicational and cognitive micromoves]. In J. Bernicot, E. Veneziano, M. Musiol, \& A. Bert-Erboul (Eds.), Interactions verbales et acquisition du langage (pp. 319-355). L'Harmattan.

Trognon, A., Batt, M., Sorsana, C., \& Saint Dizier de Almeida, V. (2011c). Argumentation and dialogue. In A. Trognon, M. Batt, J. Caelen, \& D. Vernant (Eds.), Logical properties of dialogue (pp. 147-186). Presses Universitaires de Nancy.

Trognon, A., \& Sorsana, C. (2005). Les compétences interactionnelles: Formes d'exercice, bases, effets et développement [Interactional competences: Shapes, foundations, effects and development]. Rééeducation Orthophonique, 221, 29-56.

Trognon, A., Sorsana, C., Batt, M., \& Longin, D. (2008). Peer interaction and problem solving: One example of a logical-discursive analysis of a process of joint decision making. European Journal of Developmental Psychology, 5(5), 623-643. https://doi.org/10.1080/17405620701860165

Turkle, S. (2015). Reclaiming conversation. The power of talk in a digital age. Penguin Press.

Valenzuela-Moguillansky, C., \& Vásquez-Rosati, A. (2019). An analysis procedure for the micro-phenomenological interview. Constructivist Foundations, 14(2), 123-145.

Vanderveken, D. (1990). Meaning and Speech Acts. Cambridge: Cambridge University Press.

van Eemeren, F., \& B. Garssen, B. (Eds.) (2015). Scrutinizing argumentation in practice. John Benjamins Publishing. https://doi.org/https://doi.org/10.1075/aic.9

Varela, F. J. (1996). Neurophenomenology: A methodological remedy for the hard problem. Journal of Consciousness Studies, 3, 330-349.

Varela, F. J. (1997). The naturalization of phenomenology as the transcendence of nature: Searching for mutual generative constraints. Alter: Revue de Phénoménologie, 5, 355-385.

Varela, F., Thompson, E., \& Rosch, E. (Eds.). (1991). The embodied mind: Cognitive science and human experience. MIT Press. https://doi.org/10.7551/mitpress/6730.001.0001

Veneziano, E. (Ed.). (1999). La conversation: Instrument, objet et source de connaissance [Conversation: instrument, object and source of knowledge] (pp. 7-8). Psychologie de l'Interaction.

Vermersch, P. (1994). L'entretien d'explicitation [The explicitation interview]. Editions Sociales Françaises. (Transl. in English: https://www.academia.edu/36572134/The_explicitation_interview)

Vermersch, P. (2009). Describing the practice of introspection. Journal of Consciousness Studies, 16(10-12), 20-57.

Vermersch, P. (2012). Explicitation et phénoménologie: Vers une psychophénoménologie [Explicitation and phenomenology: Towards a psychophenomenology]. Presses Universitaires de France.

Vernant, D. (1998). Du dire au faire. Les niveaux d'analyse des phénomènes communicationnels [From talking to doing. The analysis levels of communicational phenomena]. Revue d'Interaction Homme-Machine, 1(1), $11-32$.

Weil-Barais, A. (2011). Comment rendre compte des échanges dans un contexte d'apprentissage? [How taking into account verbal exchanges in a learning context?] In M.-A. Hugon \& C. Le Cunff (Eds.), Interactions dans le groupe et apprentissages (pp. 43-59). Presses Universitaires de Paris Ouest. https://doi.org/10.4000/books.pupo.3189

Wertsch, J. V. (2008). From social interaction to higher psychological processes. A clarification and application of Vygotsky's theory. Human Development, 51(1), 66-79. https://doi.org/10.1159/000112532

Zittoun, T., \& Iannaccone, A. (Eds.). (2014). Activities of thinking in social spaces. Nova.

Footnotes.

1 (a) When one thinking advance is more probable than another, (b) when relational regulations foster cognitive progress, and (c) some characteristics of the disagreements that may (or may not) favour the emergence of creative thinking.

2 Moreover, the way reasoning is purported to be a social skill is controversial (see, e.g., Dutilh Novaes, 2018).

3 Transactive dialogues are defined as "discussions in which an individual's reasoning operates their partner's reasoning" (p. 205).

4 "Exploratory talk is that in which partners engage critically but constructively with each other's ideas. Relevant information is offered for joint consideration. Proposals may be challenged and counter-challenged, but if so reasons are given and alternatives are offered. Agreement is sought as a basis for joint progress. Knowledge is made publicly accountable and reasoning is visible in the talk" (p. 153).

$5 \quad$ "In some discussions we also observed indications from the non-conserver that agreement with the conserving position was the product of progress. Such indications of understanding could be expressions of the A-ha moment such as 'Oh, now I understand!!!,' 'I see, you are right!!!' or moments where original non-conservers used conservation arguments themselves, either elaborated arguments or unelaborated general assertions. A characteristic of these discussions was also that after the turn where the indication of understanding was given the original non-conserver offered no further resistance to the conserving argument. We named these types of conversations as "Explicit recognition"” (2006, p. 415). 
"Thinking spaces are both inner zones of personal psychic activity and social opportunities to carry on this activity in sufficiently secure settings where the child or/and adolescent can risk confronting others with differing points of view and discovering new elements of reality" (2003, p. 4).

$7 \quad$ For example, prior relationships between partners before the experiment, ecological characteristics of the room where the participants were observed, etc.

$8 \quad$ This way to code behaviours and/or speech using pre-established categories is very common in experimental designs to analyse children's reasoning (e.g., Domberg et al., 2018; Harris \& Núñez, 1996; Köymen \& Tomasello, 2018; Núñez \& Harris, 1998).

9 This way to scrutinize social interactions by focusing on sequentiality is very common in ethnographic studies using ethnomethodological analysis, from a sociological approach. These studies conducted in everyday situated activities (free play, school, and/or family activities) showed how various kinds of semiotic resources (related to talk, body, interactions, materials) are mobilized and interconnected in the organization of (cognitive) activities (Corsaro, 1997; Goodwin, 2000, 2007; Greenfield \& Lave, 1982; Karlsson et al., 2017; Kyratzis, 2004; Kyratzis \& Ervin-Tripp, 1999; Kyratzis \& Jean Johnson, 2017; Kyratzis et al., 2010; Lave, 1988; Lave \& Wenger, 1991; Rogoff, 1990; Rogoff \& Angelillo, 2002; Saxe, 1988, 2002; Schliemann et al., 1997). The methodologies used in these studies are very interesting tools to critically scrutinize how knowledge and know-how are built in and through social interactions, even for the researchers who are still using experimental designs.

10 According to these researchers, individuals usually reason from premises to a conclusion in a correct way. When they make errors of reasoning, the authenticity of these errors is questioned. For example, such errors of reasoning may come from the individual's interpretation of the instruction, which does not coincide with what the experimenter wants to communicate, and/or the individual's representation of the task, which does not coincide with the experimenter's goal. So, such errors of reasoning are only apparent, due to pragmatic misunderstandings.

11 Formulation of the problem to be solved: A shopkeeper has 672 video cassettes to store. He can put 32 video cassettes on each shelf. Given that a bookcase has seven shelves, how many bookcases does he need to store all the video cassettes?

12 Using a sociometric questionnaire, children sharing affinity relationships imply reciprocal choices to do specified activities together, associated with shared emotional satisfaction.

13 Successful dyads solved the Tower of Hanoi task with four discs.

14 We thank Alain Trognon for having suggested this expression.

15 We talk about the first person's point of view here. However, from a radical perspective, the first person's point of view corresponds to an introspection that is experienced through a self-explicitation interview. Introspection that is guided by an explicitation interview is therefore a second person's point of view (Vermersch, 2012, p. 82).

16 We thank the anonymous reviewer who encouraged us to clearly mention this methodological affiliation.

17 The explicitation interview and the micro-phenomenological interview are very close to each other. At the beginning, the explicitation interview was created to describe actions. This technique was extended by Claire Petitmengin to include descriptions of emotions and feelings.

18 No study published in English with children was found (using the following key words "explicitation interview" AND "children" on PsycInfo, PsyArticles, and Google Scholar). Some authors announce an "explicitation interview" as if it was identical to the Piagetian clinical interview, without other methodological detail.

19 These descriptions uttered in order to contextualize the specified situation are called "the satellites of action" (Vermersch, 1994). They help "the interviewer (a) be aware of the area of verbalization to which the interviewee is referring, and (b) drive her attention according to these areas" (Ollagnier-Beldame \& Cazemajou, 2019, p. 411).

${ }_{20}$ We piloted an explicitation interview after this problem-solving situation. Despite the fact that the partners were able to identify a specific cognitive difficulty they both had to deal with, we failed to guide the recall process towards sensory evocation: the recall of the specific moment was submerged under several other cognitive difficulties each individual had to deal with.

21 There are five elementary speech acts (Searle, 1979; Searle \& Vanderveken, 1985): assertive (e.g., to inform, to recall, to testify to ...), directive (e.g., to order, to require, to ask ...), promissive (e.g., to promise, to threaten, ...), expressive (e.g., to express feelings, ...), and declarative speech acts (e.g., to dismiss, ...).

22 An English commentary of this French book is provided in Petitmengin (2014).

23 See the definitions of "diachronic" and "synchronic" dimensions in the comments of the concrete example we offered in the section "Can Children Be Capable of Describing Their Subjective Experience?". 
Table 1. Interlocutory analysis framework

Child A

Inter- State of

Child B

statemen
relations

Utterances Illocutory goal Propositional content

Utterances Illocutory goal Propositional content 